versity, Norfolk, VA 23508; Elinor Ebeling, 228 Clubhouse Drive, Middletown, NJ 07748; David Kaser, 2402 Rock Creek Drive, Bloomington, IN 47401; William A. Moffett, Director of Libraries,
Oberlin College, Oberlin, OH 44074; Charles B. Osburn, Dean and University Librarian, Central Library, University of Cincinnati, University and Woodside, Cincinnati, OH 45221.

\title{
A proposed planning process for the Association of College and Research
}

\section{Libraries}

\author{
Prepared by the Ad Hoc Planning Process Subcommittee \\ Susan Klingberg, Chair \\ Keith Russell, Member
}

\section{ACRL's strategy for planning over the coming years.}

\begin{abstract}
A the the January 1983 ALA Midwinter Meeting, committee to develop a planning process for the Association. The Subcommittee first outlined the elements which the process or model should include. It should: a) produce a written plan to guide ACRL for at least five years; b) have a built-in mechanism for evaluation and feedback; c) accommodate periodic reviews and updating; and d) simplify (as well as codify) the work of the ACRL Planning Committee in carrying out its responsibilities.

The model proposed in this report is a strategic planning model. The strengths of strategic planning have been widely discussed in recent management literature. In his book Academic Strategy, George Keller discusses the advantages of this approach. He describes strategic planning as active rather than passive, responsive to changing conditions, competitive, decision-oriented, and participatory (Johns Hopkins, 1983, pp.143-148). Another distinctive characteristic of strategic planning is its emphasis on formulating and evaluating alternative strategies.
\end{abstract}

Together, this report and model constitute a "plan for planning" for ACRL. It should first be reviewed and revised by the Planning Committee before being more widely distributed within ACRL. Following review and revision, the Subcommittee recommends the appointment of an ACRL Strategic Planning Task Force. The Task Force would be responsible for coordinating the planning process and writing the resulting strategic plan. When this is accomplished, the ACRL Planning Committee would take over responsibility for implementation of the plan, as well as evaluation, periodic review, and updating.

\section{The planning process}

Accompanying this report is a schematic diagram or model of the proposed planning process (see p.397). This section provides additional information about the steps in the process. The purpose of each step is explained, and related issues to be considered are discussed. Wherever possible, an appropriate group or body is named to carry out 


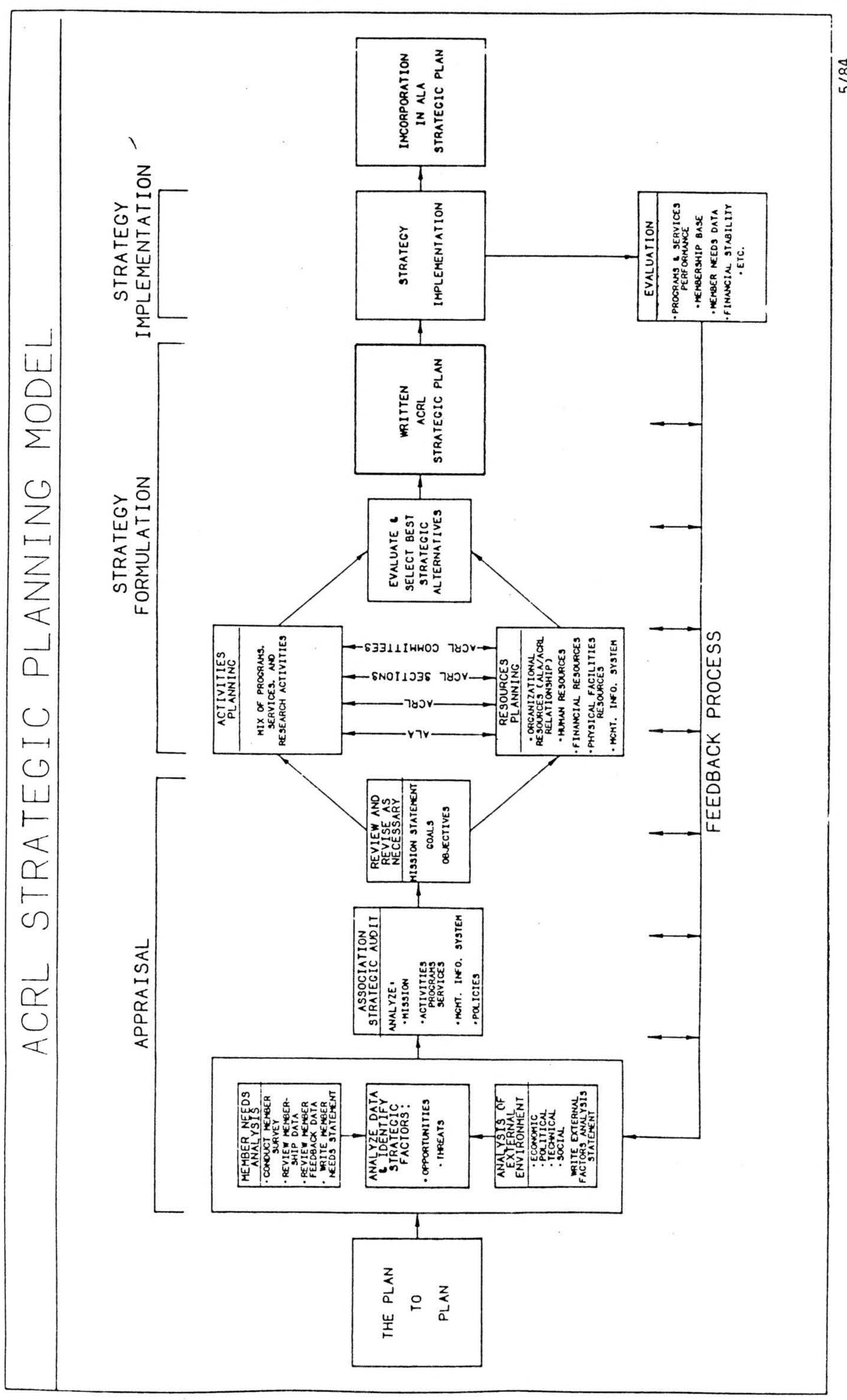



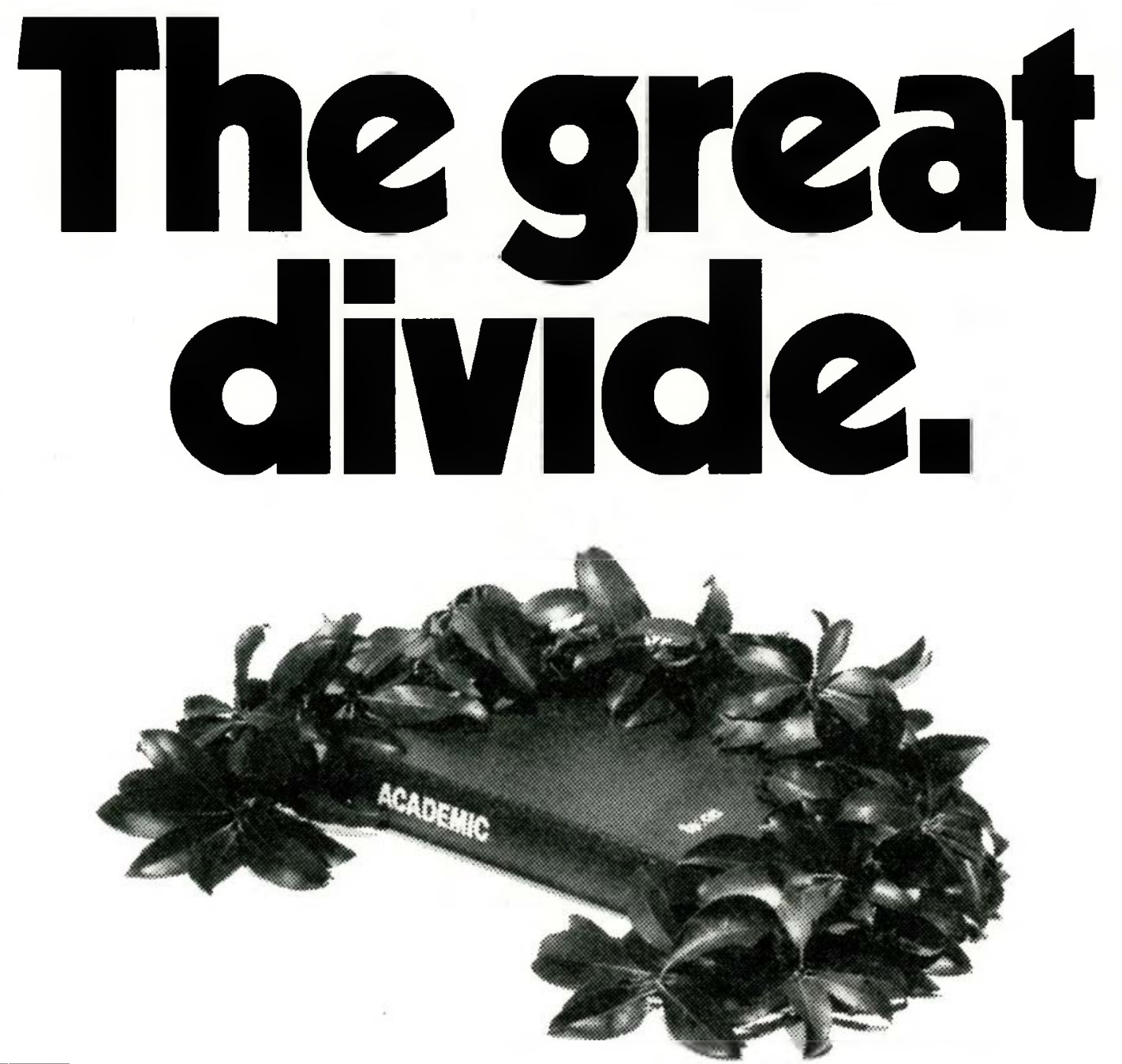

$\mathbf{F}$

axon's new Academic Division rewards you with better service. You now get the individual attention of someone familiar with your needs along with access to the vast resources commanded by Faxon.

More than 100 years of dedicated service to libraries have put Faxon at the forefront of the information frontier. We were the first agency to completely automate subscription management. First to develop an international online network. First to establish online links with major publishers.

We'll give you an edge on tomorrow. A frontier we conquer by not resting on our laurels.

$800225-6055$

or $617329-3350$

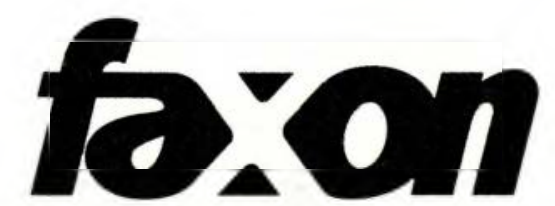

ON THE FRONTIER OF INFORMATION MANAGEMENT

The Faxon Company, Inc. 15 Southwest Park Westwood, MA 02090 
the step, and other stakeholders in the process are identified. An effort has been made to show the relationship of steps to one another. The diagram is meant to be a symbolic representation of the planning process. Aspects such as the sequence of steps should not be strictly interpreted. For example, some strategies may be approved and implemented while the plan is still being written.

The involvement of ALA, ACRL, and ACRL sections and committees is represented in steps 6 and 7 of the model, under "Strategy Formulation." Please note that these groups are involved at other steps of the process as well.

\section{Appraisal}

1. Analyze member needs. For this analysis, membership data is reviewed and trends are studied. Current members and potential members are profiled, as well as others who might make use of ACRL programs, e.g., non-ACRL members who attend ACRL continuing education programs. For these categories, both current and future needs that could be met by ACRL are identified. A formal survey of at least a sample of the membership is recommended. ACRL has not done a member needs assessment in recent years. President-elect Sharon Rogers has also expressed interest in a member survey. In addition to identifying member needs, the survey could provide feedback on the effectiveness of programs and services. Contracting with an outside consultant would be the most efficient way to conduct the survey.

Other sources of data should also be reviewed, such as membership files and evaluations from participants in ACRL continuing education programs. All of the data gathered on members and members' needs should be synthesized in a written members' needs statement. The analysis and resulting statement could be contracted out to a consulting firm experienced in member needs analyses. Another option is to assign responsibility to ACRL headquarters staff, who would work with the Membership Committee. It is expected that such an analysis could be completed in seven months. Provision should be made for updating the member needs data periodically.

2. Analyze the external environment. In this step, economic, political, technical, and social factors are reviewed which have an impact on the Association. The Activity Model Committee's final report (abbreviated AMFR; CむRL News, May 1982, pp.164-69) already does much of this, but it should be reviewed and updated to cover both current and anticipated environmental conditions.

The ACRL Planning Committee, since it has been heavily involved with the AMFR, should be given responsibility for this analysis and for the production of an external factors analysis statement. Work on this could begin at any time, and it could be completed in three months. A literature review of recent publications may be a good start- ing point.

3. Identify strategic factors. This step builds on the activities in the two preceding steps. The data collected is further analyzed and opportunities and threats facing the Association are identified and assessed. Much of this will be similar to a market analysis, where markets and competition are analyzed.

This analysis should be carried out by the ACRL Strategic Planning Task Force and should culminate in a working document which will guide subsequent planning activities. Suggested completion date is two months after step 1 is completed (i.e., the end of month 9).

4. Conduct a strategic audit. The strategic audit is a statement of ACRL's current situation and, to some extent, how it got there. It identifies the mission, activities, programs, services, policies, management information system, etc., of the Association, along with strategies it is pursuing. It also identifies and discusses the strengths and weaknesses of the Association. Much of the work for the strategic audit was done in preparing the AMFR; that work will only need updating. Another document to refer to as a model is the American Association of School Librarians' Future Structure Report (AASL, March 1984), which has elements of a strategic audit and of strategy formulation.

The ACRL Strategic Planning Task Force should work closely with ACRL headquarters staff to prepare this report. It should be completed three months after step 3 is completed (i.e., end of month 12). Step 3 should be completed before step 4 , but a good deal of the work can proceed simultaneously.

5. Review and revise as needed the ACRL mission, goals, and objectives. This step should be done with the ACRL strategic audit in hand. While the mission, goals, and objectives were revised in the preparation of the AMFR, another careful review will be necessary in light of the information turned up in steps 1-4.

This review should be carried out by the ACRL Strategic Planning Task Force. It should be completed two months after step 4 is completed (i.e., the end of month 14).

\section{Strategy formulation}

6. Carry out activities planning. First, it is necessary to refer back to the strategic audit for an analysis of the current mix of programs, services, and research activities. Recommendations can then be made to alter the mix by modifying, dropping, or adding activities.

This step can be worked on at any time, but it cannot be successfully completed before the completion of step 5. The ACRL Strategic Planning Task Force should produce written recommendations on activities within one month of the end of step 5 (i.e., the end of month 15).

7. Carry out resources planning. This step involves reviewing ACRL resources currently avail- 
able and those needed in the future. It includes organizational resources, human resources (ACRL headquarters staff and the membership), office facilities and equipment available to ACRL, financial resources, and the ACRL management information system. For financial and organizational issues, the ALA Operating Agreement will be a useful document. The advantages and constraints of the present relationship between ALA and ACRL should be studied.

A resources planning report should be completed within one month of the end of step 6 (i.e., the end of month 16). It is recommended that headquarters staff prepare the resources planning report according to guidelines from the Task Force.

8. Evaluate and select best strategic alternatives. Essentially this step brings together the step 6 and 7 reports, and decisions are made concerning the mix of activities and the resources needed to support them. An important consideration is the feasibility of implementing the various alternatives.

The ACRL Strategic Planning Task Force will do this evaluation and will prepare the following report, within two months of the end of step 7 (i.e., end of month 18).

9. Prepare a written five-year ACRL strategic plan. A five-year period was selected for the plan to cover because it is a reasonable time span in terms of forecasting. It would be difficult to make predictions any further in advance for internal factors such as member needs and for external factors such as advances in technology. Also, a five-year plan would mesh well with the Activity Model, which looks ahead to the year 1990. The first five-year plan should be developed to cover from 1986 to 1990.

The plan should focus on the strategies selected in the preceding step. It should also draw on other key steps in the planning process by synthesizing work done in the strategic audit and in the activities and resources planning reports. The plan should demonstrate how activities and services relate to organizational goals. It should provide clear and specific direction to all of the elements within ACRL (governance bodies, headquarters staff, sections, etc.). Documents such as the mission and goals statements and possibly some of the previous planning reports could be included in the appendix. The ACRL Strategic Planning Task Force produces this report (at the end of month 18) as its last major activity.

\section{Strategy implementation}

10. Implement the strategy that has been developed. The ACRL Planning Committee will oversee and coordinate the implementation of the strategies described in the written plan.

\section{Evaluation}

11. Evaluate. Since the strategic plan is designed to cover a five-year period, it could be reviewed and updated either annually or biennially. During each review, one or two years could be added to the period covered so that the plan is self-perpetuating. This review and update would be conducted by the ACRL Planning Committee, which would also evaluate the effectiveness of the plan and progress in its implementation. On an ongoing basis, the Committee would also informally monitor factors which might affect Association plans and activities.

\section{Recommendations for executing the planning process}

The subcommittee recommends the following for executing the above described planning process:

Recommendation 1. This report describing the planning process should be disseminated as widely as possible within ACRL. It should be published in College and Research Libraries News, and in other ways brought to the attention of ACRL members.

Recommendation 2. Once a revised report is accepted, an ACRL Strategic Planning Task Force should be appointed immediately to begin coordinating the planning process.

The Task Force should have 7 members, including a) at least two regular members of the ACRL Planning Committee; b) one past ACRL president; c) the ACRL executive director; d) the ACRL vice-

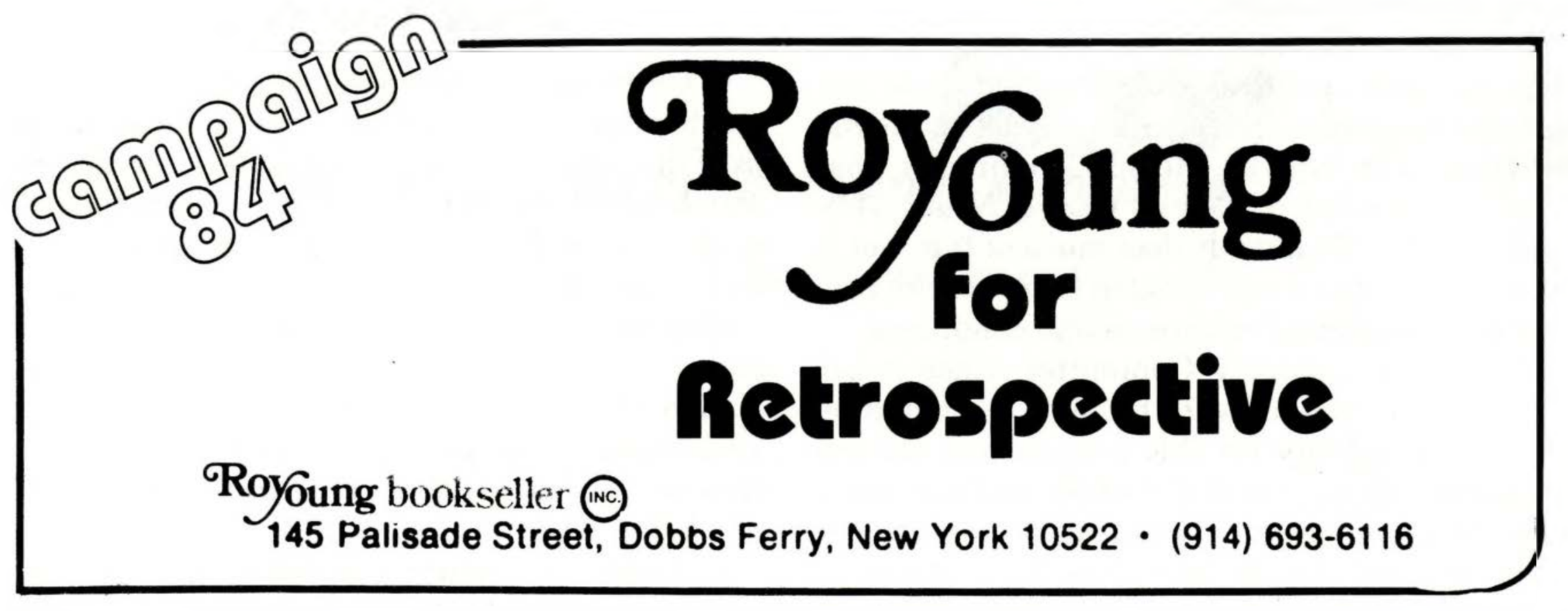


president/president elect; and e) two additional members.

Recommendation 3. To kick off the planning process, a facilitator should be hired to work with the Task Force for one day to explain considerations in strategic planning, etc.

Recommendation 4. The ACRL Board of Directors should set aside appropriate funds to support the work of the Task Force. Such funding should allow additional meetings of the Task Force beyond those possible in conjunction with ALA conferences. Perhaps extra meetings could be scheduled to coincide with ACRL executive committee meetings, which some of the Task Force members would be attending.

Recommendation 5. The target date for the completion of this project should be no later than the annual ALA conference in the summer of 1986. Based on the time estimates in this document, it will take approximately 18 months to complete the planning process.

Recommendation 6. Finally, the charge of the
Planning Committee should be revised to place more emphasis on planning as a primary responsibility. Within ACRL's governance structure, the committee should be responsible for developing plans and strategies which will help the Association achieve its goals and objectives. This responsibility is not adequately described in the current charge. In addition, the task of reviewing and revising the five-year plan should be added to the charge.

Editor's Note: The authors prepared this report as members of an ad hoc subcommittee of the ACRL Planning Committee. Susan Klingberg, chair, is from California State University, Sacramento, and Keith Russell is from the Council on Library Resources, Washington, D.C. On June 25, 1984, the full ACRL Planning Committee endorsed this report. At its meeting on June 26, 1984, the ACRL Board of Directors voted to endorse and support the planning process described in the report and to appoint a Strategic Planning Task Force.

\section{The ACRL President's Program for 1984-85}

Priorities for ACRL and for academic librarianship will be the focus of the ACRL President's Program in 1984-85. The President's Program will be a year-long series of activities requiring the involvement and commitment of hundreds of ACRL members across the country. ACRL members and their ideas about academic librarianship will be the President's Program at the annual meeting in Chicago in 1985 . They will be setting the association's priorities within the framework of the Activity Model for 1990.

\section{What IS the Activity Model for 1990 ?}

In 1980, David Weber, then the vicepresident/president-elect of ACRL, recognized the need for professional associations to engage in systematic planning to ensure the viability and relevance of the association. He appointed a committee "to review the Association's activity structure and propose such changes as appeared needed to bring it into accord with the likely demands of its second century of service to begin in 1990." This ad hoc committee (David Kaser, chair, Olive James, William J. Studer, Carla J. Stoffle, and Julie Carroll Virgo) submitted its final report in 1982. The report was adopted by the Board in 1982 as the Activity Model for 1990 and it was disseminated to all ACRL members in C\&RL News, May 1982, pp. 164-69.

\section{What ISN'T the Activity Model for 1990?}

The Activity Model for 1990 stimulated many initiatives within ACRL. For example, the charges to the task forces that past president Carla Stoffle appointed grow directly from recommendations in the Activity Model. However, useful as the Activity Model for 1990 is for stimulating growth of ACRL programs, it is not helpful for guiding decisionmaking within the association because no priorities are set. Therefore, in 1984-85, ACRL members will be asked to advise on the priorities for ACRL, by responding to a membership survey and by participating in a group decision-making process at the annual meeting.

\section{The cast of characters}

The program plan calls for a cast of hundreds to contribute their time and energy in the following ways:

-600 ACRL members will receive a survey instrument designed to guide them through the process of recommending priorities among and within major activity areas. Each of the 600 members will also be asked for some background information about themselves and their involvement in academic librarianship and in ACRL.

-10 ACRL members, primarily located in the Washington, D. C., area, will form a Research Team to review the data collection and analysis, 
and draft a report of the results.

- 5 ACRL members will form a Presentation Team to take the results from the Research Team and design a presentation of the membership survey results for the first part of the annual meeting in Chicago in 1985.

-10 ACRL members, primarily located in the Chicago area, will form a Local Arrangements Committee to handle the logistics of the annual meeting itself.

-70 ACRL members will be asked to serve as discussion leaders at the annual meeting. Names have been suggested by the chairs-elect of ACRL sections, but volunteers are still needed. Training sessions will be held during Midwinter, 1985, in Washington, D. C.

-700 ACRL members will participate in the final priority-setting activity during the annual meeting.

\section{The pay-off}

When the program is complete, at the end of the annual meeting in Chicago in 1985, ACRL will have the following information and resources to use to take the lead in anticipating the needs of the profession of academic librarianship:

1. The membership's assessment of priorities for the association's activities. The final results from the annual meeting will go to the second Board meeting in Chicago for the Board's review. Adoption of these priorities, or a modified version, will provide decision-making guidance to the Board, the Budget and Finance Committee, and the Planning Committee.

2. Demographic and attitude information from a random sample of the ACRL membership. This may be compared with demographic and attitude information from the participants in the annual meeting. Such a comparison may reveal similarities and/or differences between the general membership and the activists within the association.

3. Results to inform further planning activities. These will be recommended to the ACRL Board in 1985 by the Strategic Planning Task Force.

4. A prototype of an ACRL membership survey. Such a survey may be instituted on a scheduled basis. The program serves as a pilot study to assess techniques and costs.

\section{Stay tuned}

More information on the 1984-85 ACRL President's Program will appear in future issues of $C \mho R L$ News. In the meantime, 600 ACRL members can be watching their mailboxes for their first opportunity to participate by responding to the membership survey. - Sharon Rogers, ACRL President.

\section{ACRL/PLA grant for humanities programming}

The Association of College and Research Libraries and the Public Library Association have received a grant from the National Endowment for the Humanities to conduct workshops for academic and public librarians and humanist scholars. Six two-day workshops will be held regionally throughout the country during 1984 and 1985. The primary goal of these workshops will be to initiate communication between public and academic librarians and humanists for the purpose of working together on cooperative humanities programming projects and to stimulate them to seek funds for appropriate humanities activities.

Applications are being sought from public and academic librarians wishing to participate in these workshops. Participants will be provided lodgings and meals at the workshop site and a travel subsidy of up to $\$ 150$ per participant will be provided. Participants will be selected based on the following criteria:

-demonstrated philosophical interest in public programming;

- ability to assess each library's humanities holdings to identify potential topics for humanities programs;

-ability to assess the resources and structures of the academic institution and public libraries in terms of joint programming efforts;

-interest in learning how to develop innovative methods of programming to stimulate interest in the humanities in the general adult public using the resources of public and academic libraries; and

- potential to work cooperatively with a complementary library and humanist.

Workshop dates, locations, and deadlines are as follows:

October 17-19, 1984, St. Benedict Center, Madison, Wisconsin. Apply by September 15 (this is an extension of an earlier deadline).

December 12-14, 1984, La Casa de Maria Center, Santa Barbara, California. Apply by October 31.

March 13-15, 1985, Shakerstown, Kentucky (near Lexington). Apply by January 31 .

May 1-3, 1985, Bon Secours Center (near Baltimore, Maryland). Apply by March 22.

August 28-30, 1985, The Greenbriar, White Sulphur Springs, West Virginia. Apply by June 28.

November, 1985, Northwestern/Mountain Plains Region. Apply by September 27, 1985.

For applications contact: Barbara Macikas, NEH Project, ACRL/ALA, 50 E. Huron St., Chicago, IL 60611-2795; (302) 944-6780. 


\section{NEH gives more prominence to its Humanities Projects}

The National Endowment for the Humanities has reorganized its Division of General Programs to include a separate section for Humanities Projects in Libraries. New guidelines for the program will be available in October 1984. Along with the Division's other programs, the purpose of Humanities Projects in Libraries is to fulfill the Endowment's mandate "to foster public understanding and appreciation of the humanities." Academic, research, and public libraries are the ideal places to interpret masterpieces of art and literature for the general public and thus increase the appreciation and use of library collections by 130 million adult Americans. These projects, a cooperative effort between the nation's libraries and the Endowment, are once again being fully supported by more than $\$ 3$ million per year by the NEH.

The deadline for proposals is March 8, 1985. Projects can begin as early as September 1985 and are generally supported from one to two years.

All types of libraries are welcome. Many successful projects use a combination of types of libraries. Librarians interested in programs for out-of-school adults which use materials in their humanities collections should call the Endowment for guidance at

\section{(202) 786-0271.}

Early in 1982 a merger between Humanities Projects in Libraries and Special Projects section on Program Development was made by the Chairman's office of the Endowment. At that time guidelines for the two programs were also combined. Since libraries were only one of many institutions eligible for application through these merged programs, the name of the new guidelines became "Program Development" rather than "Libraries." As a result fewer and fewer applications for humanities programs in libraries were received during the next two and one-half years.

During 1982 the amount of money available to libraries from the Endowment for public programs was substantially reduced from more than $\$ 3$ million to less than \$1 million. In 1983 and 1984 the Congress appropriated $\$ 2.5$ million and $\$ 3.0$ million respectively. The 1982 cut in the budget was probably a contributing factor to the waning number of proposals from the field. Because fewer proposals were received, less money than was appropriated in 1983 and 1984 was awarded for projects in libraries. Consequently there is a very real need for proposals from libraries.

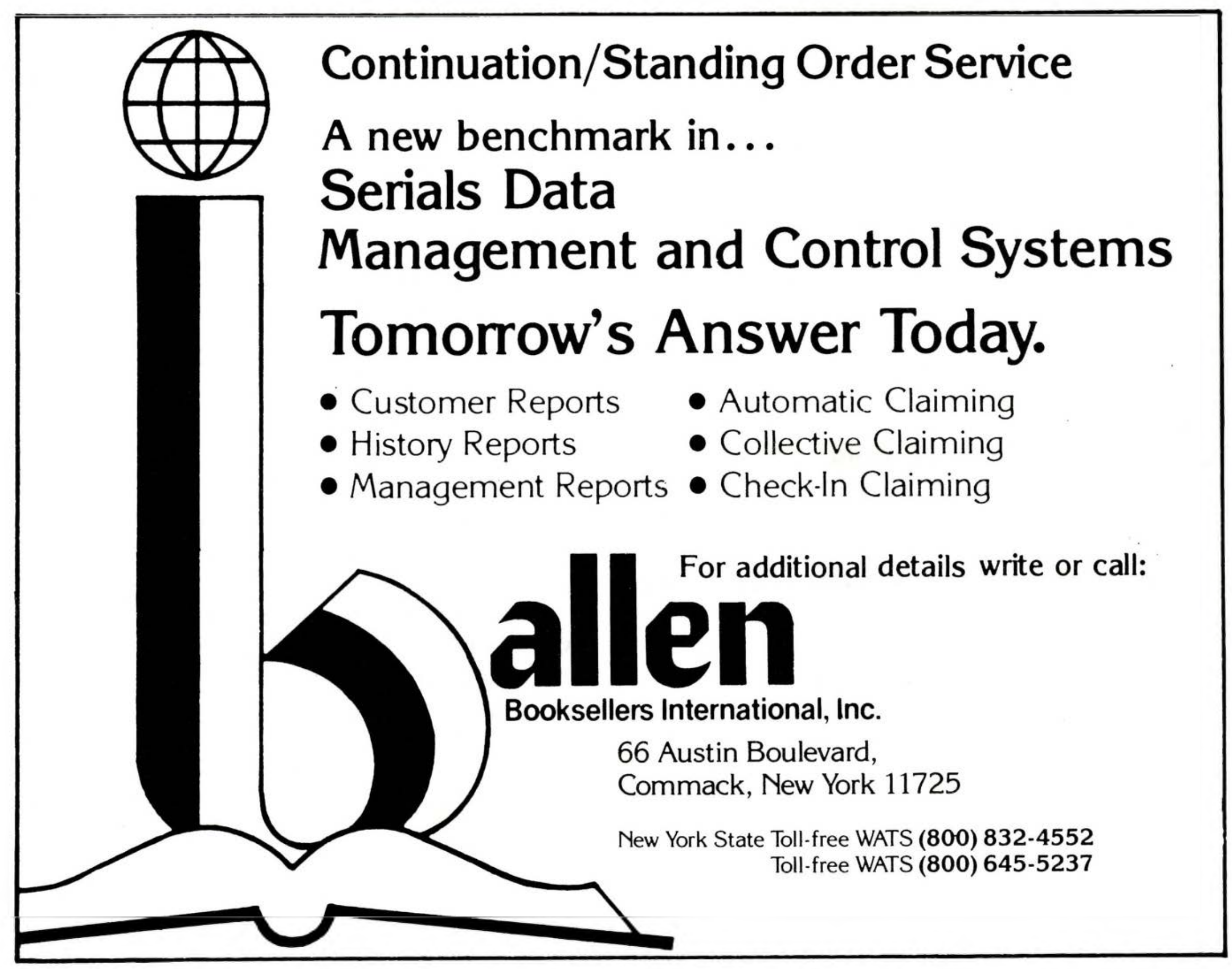


Since the merger of the programs at the Endowment, many librarians have apparently assumed that NEH was no longer as responsive to projects on humanities topics and themes through libraries. While this is not entirely true, the results were clear: fewer proposals and less money offered for support. There were only 27 proposals received in 1983, down from 78 in 1981, and by the 1984 deadlines only 37 proposals were received, of which 20 obtained Endowment support for a little less than
$\$ 2$ million.

Once again the Congress has marked a level of support for Humanities Projects in Libraries at over $\$ 3$ million for fiscal year 1985 . For more information about this renewed effort, or for guidelines on programs through libraries, call or write to: Thomas Phelps, Division of General Programs, National Endowment for the Humanties, 1100 Pennsylvania Avenue, N.W., Washington, DC 20506; (202) 786-0271.

\title{
A case study in closing the university
}

\section{library to the public}

\author{
By Brenda L. Johnson \\ Coordinator for Circulation and Interlibrary Services \\ Rutgers University Libraries
}

\section{The pros and cons of restricting access in a state-supported university library.}

Oorit n October 28, 1983, a number of Rutgers University librarians attended an ACRL tri-chapter (New York Metropolitan Area, Delaware Valley, and New Jersey) symposium based on the case study method. The symposium, "Life on The Technology Express," led one librarian, Adeline Tallau, to conceive of a similar-type program for her Rutgers' colleagues. She immediately thought of an issue of great concern to the Rutgers Library community - serving the non-Rutgers clientele.

Rutgers University Libraries' Forum on Services (a faculty group made up of librarians working in the areas of reference, interlibrary loan, circulation, online database searching, technical services and bibliographic instruction) agreed to sponsor a program entitled, "A Case Study in Closing the
University Library to the Public." On May 16 , 1984, about twenty-five librarians gathered to discuss the issues, problems and solutions generated by a pre-distributed set of documents or "case," set at the fictitious New Jersey University Library.

The mythical New Jersey University, with over 40,000 students on two campuses in New Towne and Dennison, is one of the major state university systems in the nation. According to the case, several years before her arrival at New Jersey University as the university librarian, Manfreda Edsel published the highly controversial article, "Are Libraries a Public Utility?" in which she divided public utilities into two classes-the service type and product type. Clearly, she stated, libraries are a service and "services to a group which the library 